\title{
An open economy DSGE model with search-and-matching frictions: the case of Hungary
}

\author{
Zoltán Jakab* \\ International Monetary Fund
}

\author{
István Kónya ${ }^{\dagger}$ \\ Magyar Nemzeti Bank \\ Central European University
}

\begin{abstract}
This paper builds and estimates a medium scale, small open economy DSGE model augmented with search-and-matching frictions in the labor market, and different wage setting behavior in new and existing jobs. The model is estimated using Hungarian data between 2001-2008. We find that: (i) the inclusion of matching frictions significantly improves the model's empirical fit; (ii) the extent of new hires wage rigidity is quantitatively important for key macro variables; (iii) labor market shocks do not play an important role in inflation dynamics, but the structure of the labor market influences the monetary transmission mechanism.
\end{abstract}

\section{Introduction}

This paper examines the impact of introducing search frictions and sluggish wages into an open economy DSGE model of Hungary. The model builds on the existing Hungarian DSGE model of Jakab and Világi (2008), but adds a more detailed labor market based on the Mortensen and Pissarides (1994) search-and-matching framework, and simplifies along other dimensions. Our goal with this exercise is threefold.

First, we are interested in how the search-and-matching rigidities modify the workings of the model relative to the baseline where sluggish wages are a result of Calvo wage setting by monopolistic wage setters (Erceg, Henderson and Levin 2000; Adolfson, Laséen, Lindé and Villani, 2007). A particular interest in our exercise is the role of wage rigidity for new hires. There is an ongoing debate on how much new hires wages mimic wages in existing jobs. ${ }^{1}$ We contribute to this literature by separately estimating the parameter governing new hires wage rigidity, and examining the consequences of such rigidity in a medium scale DSGE model.

Second, we explore how monetary policy and the labor market interact in a more realistic setting. ${ }^{2}$ This way we can learn about the transmission of monetary policy shocks through the labor market, and also the impact of labor market originated shocks to the rest of the economy.

\footnotetext{
* Research Department. Address: 1900 Pennsylvania Ave N.W., Washington, DC 20431. E-mail: zjakab@imf.org.

${ }^{\dagger}$ Corresponding author. Research Department (MNB), Economics Department (CEU). Address: 8-9 Szabadsag Ter, Budapest 1054, Hungary. E-mail: konyai@mnb.hu.

${ }^{1}$ Pissarides (2009) and Haefke, Sonntag and van Rens (2013) find that wages of new hires are flexible. On the other hand, Bewley (1999) and Gertler, Sala and Trigari (2008) argue that fairness and motivation lead firms to set new hires wages relative to existing jobs. Survey evidence of the Eurosystem Wage Dynamics Network also supports the latter view (see Galuscak et al., 2012 for cross-country evidence; and Kézdi and Kónya, 2011 for Hungary).

${ }^{2}$ See Berument, Dogan and Tansel (2009) for evidence in Turkey along similar lines.
} 
Finally, we contribute to the existing literature on labor DSGE models by adding search and matching rigidities to a small open economy framework. We do this primarily because the Hungarian economy is highly open, so it is essential to include the export and import sectors (as well as foreign borrowing and lending) to provide a realistic picture. On the other hand, we are able to explore interactions between labor market rigidities and openness: the impact of shocks that originate abroad on the labor market, and the impact of labor market disturbances on exports and imports.

The model we develop is built from standard elements, adopted to some of the special features of the Hungarian economy. Apart from the description of the labor market, we use a somewhat simplified version of Jakab and Világi (2008). The model has an intermediate good sector producing homogenous goods, and a differentiated final good sector. The intermediate good is produced using labor and capital. This is the sector where search and matching frictions are found. Price rigidities, on the other hand, only apply to final good producers, who assemble differentiated products using the domestic and imported intermediates. Thus we follow much of the literature and separate the wage bargaining and price setting decisions for analytical convenience (see Trigari 2006, for example).

We estimate the model by Bayesian techniques on Hungarian data. Our results indicate that new hires wage rigidity is likely to be lower then wage stickiness in existing jobs, but the parameter is very imprecisely estimated. Impulse response analysis reveals that new hires wage flexibility has important implications for at least some shocks and variables.

To judge the performance of our model, we evaluate it against an alternative that is a simplified version of Jakab and Világi (2008). In particular, we replace the search-and-matching block with a standard wage inflation Phillips curve, and include an ad-hoc specification of slow employment adjustment (as in Adolfson, Laséen, Lindé and Villani, 2007). We find that our baseline model is strongly favored by the data (based on the posterior odds ratio). Also, the impulse responses generated by the baseline model are more in line with VAR evidence on the Hungarian economy than the alternative specification (Jakab, Várpalotai and Vonnák, 2006; Vonnák 2007). ${ }^{3}$

Overall, our exercise is similar to Christoffel, Kuester and Linzert (2006), who estimate a searchand-matching augmented DSGE model on German data. Apart from the fact that they work with a closed economy, there are some other important distinctions. First, we add capital as a factor of production in addition to labor. Second, we distinguish wage rigidity for existing jobs and new hires. Pissarides (2009) shows that the wage rigidity of new hires is the important variable for job creation, while wages in existing jobs are not allocative in this class of models.

This is also an important difference - apart from the country coverage and the treatment of monetary policy - from Albertini, Kamber and Kirker (2011), who also work with a small open economy (New Zealand) but do not distinguish wage rigidity in new and existing jobs. Stahler and Thomas (2012), on the other hand, do allow for different degrees of wage stickiness for new hires. Their model, however, is designed for fiscal policy simulations in a two-country currency union, while we focus on a small open economy with its own monetary policy. Also, Stahler and Thomas (2012) rely on calibration, while we estimate our model using Bayesian methods.

We do not consider how monetary policy should be considered in the presence of matching frictions and real wage rigidity. Faia (2008) shows that with these two features, monetary policy should target not only inflation, but also unemployment. This result comes from the fact that equilibrium

\footnotetext{
${ }^{3}$ See Benczúr and Rátfai (2014) for a comprehensive description of business cycle facts in many countries, including Hungary.
} 
allocations are generally inefficient in such a framework, but the exact details of the optimal policy depend also on the calibration. Since our goal in this paper is to examine the ability of a DSGE model with search frictions to fit actual developments in Hungary, we leave the question of optimal monetary policy for future research.

\section{The model}

Our model is a standard New Keynesian model based on the estimated, small open economy framework of Jakab and Világi (2008) for Hungary. To that model, we add matching frictions as in Christoffel, Kuester and Linzert (2006); we depart from that paper by allowing different degrees of wage rigidity for new and existing jobs. Relative to Jakab and Világi (2008), we simplify by dropping adaptive learning about inflation, and by focusing on the inflation targeting period 2001-2008. This combination of an open economy DSGE framework with matching frictions and different degrees of wage rigidity is, to the best of our knowledge, novel in the literature. Similar exercise are carried out in Albertini, Kamber and Kirker (2011) and Stahler and Thomas (2012). The difference with respect to the first study is the separation of new hires' wage rigidity, while the second article is a two-country, calibrated model focusing on fiscal policy. ${ }^{4}$

\subsection{Households}

There is a measure 1 of identical households in the economy; this is also the size of the labor force. Each household has a continuum of members. The representative household maximizes intertemporal utility by selecting streams of consumption, investment and foreign bond holdings. Consumption is subject to external habits, and investment is subject to adjustment costs defined on the ratio of current and previous investment.

Household members are either employed or unemployed; we do not model labor force participation. We use the usual assumption in the labor DSGE literature (see Merz, 1995 and Andolfatto, 1996) and assume that households provide perfect consumption insurance for their members. Thus the marginal utility of income is the same for workers and the unemployed, and we can use the representative consumer assumption in what follows. A fraction $n_{h, t}$ of the representative household $h$ works and hence suffers the disutility from work $\chi_{t}$, where $\chi_{t}$ is stochastic with an expected value of $\bar{\chi}$. The unemployed $\left(1-n_{h, t}\right)$ draw unemployment benefits $z_{u}$, which are financed by lump-sum taxes included in the term $d_{t}$.

Household $h$ 's problem thus can be written as

$$
\max \mathbb{E}_{0} \sum_{t=0}^{\infty} \beta^{t}\left[\frac{\left(C_{h, t}-v C_{t-1}\right)^{1-\vartheta}}{1-\vartheta}-\chi_{t} n_{h, t}\right]
$$

\footnotetext{
${ }^{4}$ For the sake of brevity, we report only the most important aspects of the model. A detailed description is given in an unpublished Appendix, available from the authors upon request.
} 


$$
\begin{aligned}
& \text { s.t. } \quad C_{h, t}+I_{h, t}+\frac{B_{h, t}}{P_{t} R_{t} e^{\epsilon_{t}^{r}}}=\frac{B_{h, t-1}}{P_{t}}+n_{h, t} \frac{W_{t}}{P_{t}}+\left(1-n_{h, t}\right) z_{u}+r_{t}^{k} x_{t} K_{h, t-1} \\
& -\frac{a_{0}}{1+v} x_{h, t}^{1+v} K_{h, t-1}+d_{h, t} \\
& K_{h, t}=(1-\delta) K_{h, t-1}+\left[1-\Phi\left(\frac{e^{\epsilon_{t}^{I}} I_{h, t}}{I_{h, t-1}}\right)\right] I_{h, t} \text {, }
\end{aligned}
$$

where $C_{h, t}$ is consumption, $C_{t-1}$ is average (aggregate) consumption in the previous period, $n_{h, t}$ is the employment rate, $I_{h, t}$ is investment, $B_{h, t}$ is foreign bonds held by the household expressed in local currency, $R_{t}$ is the gross domestic interest rate, $P_{t}$ is the consumer price index, $W_{t}$ is the nominal wage rate, $r_{t}^{k}$ is the (real) rental rate on capital, $K_{h, t-1}$ is the capital stock carried over from the previous period, $x_{h, t}$ is the endogenous capacity utilization of the capital stock, and $d_{h, t}$ is lump sum net income from other sources such as dividends and government transfers. The interest rate households face is subject to a stochastic shock $\epsilon_{t}^{r}$, while $\epsilon_{t}^{i}$ is an investment specific shock. We assume that the investment adjustment cost $\Phi(\cdot)$ is increasing and convex, with $\Phi(1)=\Phi^{\prime}(1)=0$ and $\Phi^{\prime \prime}(1)>0$. Capacity utilization is also subject to a convex cost, with $v>0$.

\subsection{The wholesale sector}

The wholesale sector produces a homogenous product, using capital and labor. Capital is rented from households at the competitive rental rate $r_{t}^{k}$. The labor market is subject to search-and-matching frictions. Each job is a firm-worker pair, subject to an exogenous, stochastic job destruction probability $\rho_{t}$. Firms use the same technology. The production function is given by the following Cobb-Douglas specification

$$
y_{t}=e^{a_{t}}\left(x_{t} k_{t}\right)^{\alpha}
$$

where $y_{t}$ is the amount of output produced per worker (firm), $a_{t}$ is an exogenous productivity shock, and $k_{t}$ is capital per worker.

Given the Cobb-Douglas specification and the fact that the capital market is competitive, demand for capital is given by $P_{t} r_{t}^{k} x_{t} k_{t}=\alpha P_{w, t} y_{t}$, where $P_{w, t}$ is the nominal price of wholesale goods. The equation implies that the real flow benefit of a job match for a firm is given by $z_{t} \equiv(1-\alpha) p_{w, t} y_{t}$, where $p_{w, t}=P_{w, t} / P_{t}$ is the relative price of the wholesale good.

\subsubsection{Job flows}

As is typical in the literature, new jobs are created when unemployed workers meet open job vacancies. The number of matches is described by a constant returns to scale, Cobb-Douglas matching function $m_{t}=\sigma_{m} v_{t}^{\sigma} u_{t}^{1-\sigma}$, where $m_{t}$ is the number of new matches, $v_{t}$ is the number of open vacancies, and $u_{t}$ is the number of those searching for a job. We follow the timing convention of Gertler, Sala and Trigari (2008). Employment $n_{t}$ evolves according to the flow equation

$$
n_{t}=\left(1-\rho_{t}\right) n_{t-1}+m_{t}
$$

where $\rho_{t}$ is the exogenous, stochastic separation rate and we assume a match becomes productive immediately. The number of searchers is given by $u_{t}=1-n_{t-1}$. Workers who loose their jobs have to wait one period to be able to search for a new one, so $u_{t}$ is different from the number of unemployed 
eligible for benefits, $1-n_{t}$. For future reference, we use the following (standard) notation: $q_{t}=m_{t} / v_{t}$ is the job filling rate, $s_{t}=m_{t} / u_{t}$ is the job finding rate, and $\theta_{t}=v_{t} / u_{t}$ is labort market tightness.

\subsubsection{Average wage}

We base our description of the wage setting process on Bodart, Pierrard and Sneessens (2006) and on Konya and Krause (2009). We distinguish between wages of new hires, and wages in existing jobs. This distinction has potentially important consequences for the job creation process, as shown by Pissarides (2009). In particular, wage rigidity influences job creation only if new hires wages are not fully flexible.

Both wage setting processes are described by a Calvo probability. In particular, nominal wages in existing jobs are bargained with a probability of $1-\gamma_{w}$, otherwise the wage is given by last period's nominal wage multiplied by an indexation term using current inflation. For new hires, the nominal wage is negotiated with probability $1-\delta_{w}$, otherwise it is set at last period's average wage $W_{t-1}$, again multiplied by the same indexation term. The parameter governing indexation allows us to nest nominal wage rigidity (where the nominal wage stays constant), and real wage rigidity (where wages are fully indexed to current inflation). We use the notation of $W_{t}^{*}$ to indicate wages that are set optimally in period $t$.

The evolution of the average wage depends both on the newly set wage and on those wages that are not allowed to reset. The economy wide average nominal wage $W_{t}$ evolves according to

$$
W_{t}=\frac{m_{t}}{n_{t}}\left[\delta_{w} W_{t-1} \Pi_{t}^{\vartheta_{w}}+\left(1-\delta_{w}\right) W_{t}^{*}\right]+\frac{\left(1-\rho_{t}\right) n_{t-1}}{n_{t}}\left[\gamma_{w} W_{t-1} \Pi_{t}^{\vartheta_{w}}+\left(1-\gamma_{w}\right) W_{t}^{*}\right],
$$

where $\Pi_{t}=P_{t} / P_{t-1}$ is gross inflation. Notice that $\vartheta_{w}=0$ implies nominal wage rigidity, while $\vartheta_{w}=1$ means real wage rigidity. Our wage equation can be viewed as a more micro-founded version of the real wage adjustment process (eq. 8) in Blanchard and Gali (2007). As we show below, the driving process for wage inflation is the underlying flexible wage, just as in Blacnhard and Gali (2007). Differently from their model, because of search and matching frictions, the flexible wage in our framework is not equal to marginal cost.

\subsubsection{Firms}

Let $V_{t}$ denote the value of a vacancy and let $\mathscr{J}_{t}$ denote the value of a filled job in real terms. Creating a vacancy costs $\kappa$ units, which we assume to be constant ${ }^{5}$. A vacancy is filled with probability $q_{t}$ and the wage bargain takes place with probability $\delta_{w}$. We assume the usual free entry condition to post a vacancy, which implies that the value of vacancies is identically zero, $\mathcal{V}_{t} \equiv 0$. $\mathcal{V}_{t}$ is thus given by

$$
\mathcal{V}_{t}=-\kappa+q_{t}\left[\delta_{w} \mathscr{J}_{t}\left(W_{t-1}\right)+\left(1-\delta_{w}\right) \mathscr{J}_{t}\left(W_{t}^{*}\right)\right] .
$$

\footnotetext{
${ }^{5}$ Christoffel, Kuester and Linzert (2006) assume that vacancy costs are given by $\kappa / \lambda_{t}$, which makes these costs procyclical. On the other hand, Yashiv (2006) and Fujita and Ramey (2007) argue for countercyclical vacancy costs, since these amplify unemployment fluctuations. Since we include wage rigidity and a large set of shocks, and hence do not need extra amplification, we opt for the simplest case of constant vacancy costs.
} 
Let $\mathscr{J}_{t}\left(W_{t}^{*}\right)$ denote the value of a job that was renegotiated at $t$, and it is given by

$$
\mathscr{J}_{t}\left(W_{t}^{*}\right)=z_{t}-\frac{W_{t}^{*}}{P_{t}}+\beta \mathbb{E}_{t} \frac{\lambda_{t+1}}{\lambda_{t}}\left(1-\rho_{t+1}\right)\left[\gamma_{w} \mathscr{J}_{t+1}\left(W_{t}^{*}\right)+\left(1-\gamma_{w}\right) \mathscr{J}_{t+1}\left(W_{t+1}^{*}\right)\right] .
$$

\subsubsection{Workers}

Unemployed workers receive an income $z_{u}$ while unemployed, which includes unemployment and other welfare benefits (we include the value of leisure as an additional term). We use $\mathscr{U}$ and $\mathbb{W}(\cdot)$ to denote the value functions of unemployed workers and the value functions of workers with a job, respectively (in real terms). The value of unemployment can be written as:

$$
\mathscr{U}_{t}=z_{u}+\beta \mathbb{E}_{t} \frac{\lambda_{t+1}}{\lambda_{t}}\left\{s_{t}\left[\delta_{w} \mathscr{W}_{t+1}\left(W_{t}\right)+\left(1-\delta_{w}\right) \mathscr{W}_{t+1}\left(W_{t+1}^{*}\right)\right]+\left(1-s_{t}\right) \mathscr{U}_{t+1}\right\} .
$$

The value of a job when the wage is just negotiated is given by

$$
\mathscr{W}_{t}\left(W_{t}^{*}\right)=\frac{W_{t}^{*}}{P_{t}}-\frac{\chi_{t}}{\lambda_{t}}+\beta \mathbb{E}_{t} \frac{\lambda_{t+1}}{\lambda_{t}}\left\{\left(1-\rho_{t+1}\right)\left[\gamma_{w} \mathscr{W}_{t+1}\left(W_{t}^{*}\right)+\left(1-\gamma_{w}\right) \mathscr{W}_{t+1}\left(W_{t+1}^{*}\right)\right]+\rho_{t+1} \mathscr{U}_{t+1}\right\}
$$

\subsubsection{Wage bargaining}

When wages are negotiated, we assume that they are set as a solution to the generalized Nash bargaining problem, as it is standard in the literature. Thus the wage $W_{t}^{*}$ solves

$$
\max _{W_{t}^{*}}\left[\mathscr{W}_{t}\left(W_{t}^{*}\right)-\mathscr{U}_{t}\right]^{\eta} \mathscr{J}_{t}\left(W_{t}^{*}\right)^{1-\eta}
$$

where the parameter $\eta$ measures the bargaining power of workers.

We can define define the "flexible real wage" or "Nash wage" as

$$
\omega_{t}=\eta\left(z_{t}+\beta \kappa \mathbb{E}_{t} \frac{\lambda_{t+1}}{\lambda_{t}} \theta_{t+1}\right)+(1-\eta)\left(z_{u}+\frac{\chi_{t}}{\lambda_{t}}\right)
$$

which would be the wage under continuous Nash bargaining. Solving the wage bargaining problem and using (1) yields the following log-linearized wage Phillips curve ${ }^{6}$ :

$$
\begin{aligned}
\hat{\pi}_{w, t}-\vartheta_{w} \hat{\pi}_{t} & =\frac{\beta\left[(1-\bar{\rho}) \gamma_{w}-\bar{s} \vartheta \delta_{w}\right]}{\bar{\rho} \delta_{w}+(1-\bar{\rho}) \gamma_{w}} \mathbb{E}_{t}\left(\hat{\pi}_{w, t+1}-\vartheta_{w} \hat{\pi}_{t+1}\right) \\
& +\frac{\left[1-\bar{\rho} \delta_{w}-(1-\bar{\rho}) \gamma_{w}\right]\left[1-\beta \gamma_{w}(1-\bar{\rho})\right]}{\rho \delta_{w}+(1-\bar{\rho}) \gamma_{w}}\left(\hat{\omega}_{t}-\hat{w}_{t}\right),
\end{aligned}
$$

where $\hat{\pi}_{t}^{w}$ is nominal wage inflation, $\hat{\pi}_{t}$ is the inflation rate, and $\hat{w}_{t}=\hat{W}_{t}-\hat{P}_{t}$ is the real wage.

\subsubsection{Job creation}

Imposing the free entry condition for vacancy creation leads to the the job creation condition, which can be written in log-linearized form as:

\footnotetext{
${ }^{6}$ In what follows we use variables with a hat to indicate log deviations from the steady state.
} 


$$
\begin{aligned}
\hat{q}_{t}= & \beta(1-\bar{\rho}) \mathbb{E}_{t} \hat{q}_{t+1}+\frac{\bar{s}}{\kappa \bar{\theta}}\left[\bar{w} \hat{\omega}_{t}-\bar{\xi}\left(\hat{p}_{w, t}+\hat{y}_{t}\right)\right]-\beta(1-\bar{\rho})\left(\mathbb{E}_{t} \hat{\lambda}_{t+1}-\hat{\lambda}_{t}\right)+\beta \bar{\rho} \mathbb{E}_{t} \hat{\rho}_{t+1} \\
& +\frac{\delta_{w} \bar{s} \bar{w}}{\kappa \bar{\theta}\left[1-\bar{\rho} \delta_{w}-(1-\bar{\rho}) \gamma_{w}\right]\left[1-\beta \gamma_{w}(1-\bar{\rho})\right]}\left[\beta(1-\bar{\rho}-\bar{s}) \mathbb{E}_{t} \tilde{\pi}_{t+1}^{w}-\tilde{\pi}_{t}^{w}\right]
\end{aligned}
$$

Notice that if there is no wage rigidity for new hires, i.e. $\delta_{w}=0$, the job creation condition is identical to the one under continuous Nash bargaining ${ }^{7}$. With wage rigidity for new hires, however, job creation responds not only to next period shocks, but also to the evolution of the average wage. Once $\delta_{w}>0$, moreover, also the rigidity of wages in existing jobs matters for job creation. When creating vacancies, and when wage setting for those new jobs is not completely flexible, rational firms foresee that they may remain stuck with those wages for some time.

\subsection{Final goods}

The final good sector contains a continuum of monopolistically competing firms of measure 1 . They combine the homogenous wholesale good and an imported good, and produce a differentiated final good using a CES technology, which is described by the following (real) marginal cost function:

$$
m c_{t}=\left[\alpha_{w} p_{w, t}^{1-\xi}+\left(1-\alpha_{w}\right) p_{m, t}^{1-\xi}\right]^{\frac{1}{1-\xi}} .
$$

Here $m c_{t}$ is the real marginal cost of a typical final good producer, and $p_{m, t}=P_{m, t}^{*} \mathscr{E}_{t} / P_{t}$ is the domestic relative price of the imported good. We assume that the foreign price of imports $P_{m, t}^{*}$ follows an exogenous process, and $\mathscr{E}_{t}$ is the nominal exchange rate.

Varieties are either sold domestically or exported. Consumers at home and abroad value the differentiated final goods according to the following CES utility function:

$$
Y_{j, t}=\left[\int_{0}^{1} Y_{j, t}(i)^{\frac{1}{1+\mu_{j, t}}} d i\right]^{1+\mu_{j, t}},
$$

where $Y_{j, t}(i)$ is a typical variety in sector $j=d, x$ (domestic end export), and $\mu_{j, t}$ is a time-varying markup parameter.

Variety producers act as monopolists, and choose prices when allowed. We assume pricing to market and local currency pricing. We use the well-known Calvo assumption, so that firms can reoptimize prices with probability $1-\gamma_{j}, j=d, x$. Those firms that do not optimize at the given date follow a rule of thumb. Rule of thumb price setters partially increase their prices by the average rate of past inflation, as in Smets and Wouters (2003).

After log-linearization, we arrive at the hybrid New Keynesian Phillips curve identical to that found in Smets and Wouters (2003). Using $\hat{\pi}_{t}$ for domestic inflation and $\hat{\pi}_{x, t}$ for export price inflation

\footnotetext{
${ }^{7}$ This is the point made by Pissarides (2009): "In the search and matching model, the timing of wage payments during the job's tenure is not important for job creation. Job creation is driven by the difference between the expected productivity and the expected cost of labor in new matches. ... as long as the firm and the worker use the Nash wage rule to split rents at the time of job creation, the job creation conditions are unaffected by the rule used to split rents in ongoing jobs. So wages in continuing jobs may be completely fixed, and yet, if wages in new matches satisfy the Nash wage equation, the volatility of job creation will be unaffected by their wage stickiness." (p. 1340)
} 
(denominated in foreign currency), we get the following Phillips curves for sectors $j=d, x$ :

$$
\begin{aligned}
\hat{\pi}_{t} & =\frac{\beta}{1+\beta \vartheta} \mathbb{E}_{t} \hat{\pi}_{t+1}+\frac{\vartheta}{1+\beta \vartheta} \hat{\pi}_{t-1}+\frac{(1+\beta \gamma)(1-\gamma)}{\gamma(1+\beta \vartheta)}\left(\hat{m} c_{t}+\hat{\mu}_{t}\right) \\
\hat{\pi}_{x, t} & =\frac{\beta}{1+\beta \vartheta_{x}} \mathbb{E}_{t} \hat{\pi}_{x, t+1}+\frac{\vartheta_{x}}{1+\beta \vartheta_{x}} \hat{\pi}_{t-1}+\frac{\left(1+\beta \gamma_{x}\right)\left(1-\gamma_{x}\right)}{\gamma_{x}\left(1+\beta \vartheta_{x}\right)}\left(\hat{m} c_{t}-\hat{P}_{x, t}^{*}-\hat{\Xi}_{t}+\hat{\mu}_{x, t}\right),
\end{aligned}
$$

where $\Xi_{t}=\mathscr{E}_{t} / P_{t}$ is the real exchange rate.

\subsection{Equilibrium}

The wholesale sector is composed of $n_{t}$ firms producing $y_{t}$ units of the wholesale good each. The equilibrium condition on the domestic wholesale market is

$$
n_{t} y_{t}=\int_{0}^{1} Y_{w, t}(i) d i \equiv Y_{w, t} .
$$

Domestic final goods are used for consumption, investment, and government consumption. The latter is assumed to be exogenous and unproductive, described by an autoregressive process. Government consumption is included both as an accounting term in the GDP identity, and also as an exogenous demand shock that was important in Hungary in the estimation period. The government budget constraint is balanced through lump-sum taxes that are included in the term $d_{h, t}$ in the household budget constraint in Section 2.1. The domestic equilibrium condition is then given as

$$
Y_{d, t}=C_{t}+I_{t}+G_{t}+a d j_{t}
$$

where $C_{t}$ and $I_{t}$ are aggregate household consumption and investment, and $a d j_{t}$ is a term capturing costs of vacancy creation and capacity utilization.

We assume that the country is a small open economy, which has two implications for external links. First, a modified UIP condition holds, where the interest rate on home currency denominated foreign bonds is given by the constant world interest rate $1 / \beta$, plus a risk premium term:

$$
\left.\frac{\mathscr{E}_{t} R_{t}}{\mathbb{E}_{t} \mathscr{E}_{t+1}}=\frac{1}{\beta}+\psi\left[e^{-\left(B_{t}-\bar{B}\right)}-1\right]\right)+e^{\epsilon_{t}^{U I P}}
$$

We follow Schmitt-Grohé and Uribe (2003) and make part of the risk-premium a function of the net foreign asset position $B$. We also include an exogenous risk premium shock $\epsilon_{t}^{u i p}$.

Second, we posit an ad-hoc export demand equation, which is subject to habit formation:

$$
\frac{Y_{x, t}}{v_{x} Y_{x, t-1}}=\left(P_{x, t}^{*}\right)^{-\theta_{x}} Y^{w} e^{\epsilon_{t}^{x}}
$$

The variable $\epsilon_{t}^{x}$ is a foreign demand shock.

Monetary policy is represented by a simple log-linearized Taylor rule:

$$
\hat{r}_{t}=\zeta_{r} \hat{r}_{t-1}+\left(1-\zeta_{r}\right)\left(\zeta_{\pi} \mathbb{E}_{t} \hat{\pi}_{t+1}+\zeta_{e} \hat{\varepsilon}_{t}\right)+\epsilon_{t}^{m}
$$

where $\varepsilon_{t}$ is exchange rate depreciation and $\epsilon_{t}^{m}$ is a shock to monetary policy. The exchange rate is 
included because in the sample period the Hungarian currency regime was a managed float.

\section{Bayesian estimation}

The model is estimated using Bayesian techniques. Some parameters that correspond to steady state averages are calibrated. We also calibrate others that are either standard in the literature, or that are hard to identify. Since our interest is to a large extent in wage and price setting, we estimate most of the parameters related to these aspects of the model.

The estimation of the DSGE model uses Hungarian quarterly data for twelve macroeconomic variables: real consumption, real investments, real exports, real imports, real government consumption, real wages, employment, CPI inflation rate, nominal interest rate, import and export prices denominated in foreign currency, and the exchange rate. All real variables are HP-filtered with the standard smoothing parameter $(\lambda=1600)$ for quarterly data. We also experimented with vacancy data, but due to its poor quality we did not rely on it in the final estimation. The estimation sample covers the period of 2001:Q3-2008:Q3. The start of the period is determined by the adoption of inflation targeting in Hungary. We do not include the Great Recession period in the sample: our linearized method is poorly equipped to handle large shocks and possible structural breaks, and on the empirical side it is yet unclear what is the appropriate separation of trend and cyclical behavior after 2008:Q3. ${ }^{8}$

We include 12 structural shocks along with the 12 observable series. As detailed above, these are shocks to the household interest rate, the disutility of labor, investment, intermediate production technology, separation rate, export demand, the UIP condition, the foreign currency import price, government consumption, monetary policy, and the domestic and export markups. The first nine follow AR(1) processes, while the last three are white noise.

\subsection{Calibration and priors}

The discount rate $\beta$ is calibrated to match a steady state annualized real interest rate of $4 \%$, and the depreciation rate is set to $\delta=0.027$. The capital coefficient in wholesale production $\alpha$ is set to equal capital's share in national income. The parameter $\alpha_{d}$ is pinned down by the share of imports in gross output. The shares of investment and government spending correspond to averages in the national accounts.

We set the elasticity of substitution between domestic and imported intermediates to $\xi=0.8$, to capture the idea that substitution is relatively difficult in the short run. We take the capital utilization parameter $v$ from Jakab and Világi (2008). The debt elasticity of the foreign currency interest rate $\psi$ is higher than in Schmitt-Grohé and Uribe (2003), but much lower than estimated values such as in García-Cicco, Pancrazi and Uribe (2010), whose median estimate is 2.8. Our value is in the range estimated by Magyari (2010) for Hungary. We fix the intertemporal elasticity parameter $\vartheta=2$ at a standard value in the literature. Finally, as common in the literature, the steady state mark-ups are set to $\mu=\mu_{x}=0.1$.

$<$ Table 1 about here $>$

The value of the matching function elasticity is set to $\sigma=0.5$, which is standard in the literature; Petrongolo and Pissarides (2001) argue that this is in the reasonable range of estimates. Also in line

\footnotetext{
${ }^{8}$ See Yilmazkuday (2008) for evidence on structual breaks in transition economies.
} 
with the literature, for workers' bargaining power we impose the Hosios condition and set $\eta=\sigma=$ 0.5. The (steady state) job finding rate is taken from Hobijn and Sahin (2009), who compute these rates for OECD countries. The quarterly value for Hungary is $\bar{s}=0.19$. Finally, we use the average unemployment rate between 1995-2012 to pin down the steady state unemployment rate at $\bar{u}=0.08$.

The value of non-labor activity is difficult to reliably calibrate. It is a combination of unemployment benefits and the value of leisure. For the unemployment replacement rate $z_{u} / \bar{w}$ we use the value reported by the OECD for Hungary ${ }^{9}$. Since we lack reliable references for the second component $\left(\frac{\bar{\chi} / \overline{\bar{\lambda}}}{\bar{w}}\right)$, we estimate it. Note that we allow for a shock to the outside option given the large changes in policy in the sample period.

The remaining labor market parameters and moments can be calculated from steady state conditions. We use the definition of the job finding rate and the equation $\bar{n}=1-\bar{u}$ to get the separation rate, which is

$$
\bar{\rho}=\frac{\bar{s} \bar{u}}{1-u} .
$$

For the chosen values for $\bar{s}$ and $\bar{u}$, the implied value is $\bar{\rho}=0.0165$. This is much lower than in the US, but comparable to European numbers and very similar to Hobijn and Sahin (2009). The steady state level of vacancies is hard to measure, but luckily we only need to compute $\kappa \bar{\theta}$ to solve the model. This can be done using the steady state wage equation and job creation condition, along with the wage rate.

Prior distributions for the estimated parameters are shown in the first three columns of Table 2. All the standard deviations of the shocks are assumed to be distributed as an inverted Gamma distribution with mean and standard error of 1 percent. Prior distributions of the autoregressive parameters are Beta with mean 0.5 and standard error of 0.15 for all shocks. Prior distributions for the rest of the estimated parameters are shown in Table 2. Loose priors for the Calvo and indexation parameters are assumed and they were set to be equal to a Beta with mean 0.5 and standard error of 0.15 .

\subsection{Estimation results}

Columns 4-6 in Table 2 contain the estimation results. The price Calvo parameter $\gamma$ is estimated quite precisely, and indicates that firms change prices every fourth quarter. This is in line with other sources of evidence for Hungary, for example firm survey data (Kézdi and Kónya, 2011). Pricing in the export sector is more flexible.

The data is not particularly informative about the indexation parameters. The policy rule parameter posteriors are also similar to the priors, except for the exchange rate change, which is much lower.

$<$ Table 2 about here $>$

The wage Calvo parameter for existing jobs is precisely estimated, and it is significantly lower than what is suggested in Kézdi and Kónya (2011), who find that the average survey response is about 4 quarters. Neither the wage indexation nor the new hire's Calvo parameter are different from the priors. Overall, while most of the estimated parameters are sensible, in many cases identification is not very strong.

\footnotetext{
${ }^{9}$ OECD, Benefits and wages: tax-benefit indicators (2007).
} 


\section{Evaluation}

Now we turn to the evaluation of our estimated model. First, we compare our baseline results to an alternative model without search and matching frictions. This exercise highlights the role of matching frictions in the propagation of shocks. Second, we present impulse responses and shock decompositions to learn about the role of labor and non-labor shocks in generating fluctuations. In these, we pay special attention to the role of new hires wage rigidity, where we contribute to the literature by providing a quantitative evaluation in a medium scale DSGE model.

\subsection{Model comparison}

To evaluate how our model fits the data overall, it is useful to find a comparison point. For that purpose, we also estimated a somewhat simplified version of Jakab and Világi (2008), which in turn build on Smets and Wouters (2003) and Erceg, Henderson and Levin (2001). We call this the "EHL" model, and refer to our baseline specification as the "SM" (Search and Matching) model.

To make the comparison as close as possible, we replaced the labor market block of our baseline, but kept the rest of the model unchanged. In the EHL model, instead of the search and matching specification, wages are set by households supplying differentiated labor varieties, subject to Calvo-type wage setting frictions. To take account of the slow adjustment of employment, an ad-hoc Phillipscurve type equation is also specified for employment, where the driving force is the desired amount of total hours demanded by firms.

Since the derivations are standard (see, for example, Adolfson, Laséen, Lindé and Villani, 2007), here we simply reproduce the two main labor market equations:

$$
\begin{aligned}
\hat{\pi}_{w, t}-\vartheta_{w} \hat{\pi}_{t} & =\beta \mathbb{E}_{t}\left(\hat{\pi}_{w, t+1}-\vartheta_{w} \hat{\pi}_{t+1}\right)+\frac{\left(1-\gamma_{w}\right)\left(1-\beta \gamma_{w}\right)}{\gamma_{w}\left(1+\sigma_{w} \varphi\right)}\left(\varphi \hat{H}_{t}-\hat{\lambda}_{t}-\hat{w}_{t}+\hat{\chi}_{t}\right) \\
\hat{n}_{t}-\hat{n}_{t-1} & =\beta \mathbb{E}_{t}\left(\hat{n}_{t+1}-\hat{n}_{t}\right)+\frac{\left(1-\gamma_{n}\right)\left(1-\beta \gamma_{n}\right)}{\gamma_{n}}\left(\hat{H}_{t}-\hat{n}_{t}\right)+\epsilon_{t}^{n}
\end{aligned}
$$

where $H_{t}$ stands for total hours, $\sigma_{w}$ is the elasticity of substitution between labor varieties, and $\varphi$ is the inverse Frisch elasticity of labor supply. These two equations replace 7, 8, and all conditions in the baseline SM model linking employment, unemployment and job flows. As stated before, all other equations of the SM and EHL models are the same.

The labor supply shock, $\chi$ is also the same in both specifications, but we replaced the separation rate shock with an employment shock $\epsilon_{t}^{n}$. By making employment sluggish and subject to an exogenous shock, we want to give the EHL model a chance to fit the data as well as or better than the SM model.

$<$ Table 3 about here >

Table 3 reports some comparisons between the two estimation results. The main conclusion is that even though the reduced form equations are very similar, the search and matching model fits the data significantly better. Based on the log data densities reported in the table, the posterior odds ratio strongly favors the SM model. As emphasized above, we get this result despite the fact that the two models share the same reduced form specifications for employment and nominal wage inflation. 
The selected parameter estimates reported in Table 3 are quite similar ${ }^{10}$. The only meaningful differences are for the consumption habit parameter, which is lower under the SM specification, and for the wage Calvo parameter, which is higher in the SM model. For the latter, the SM wage Calvo estimate - while still too low - is closer to what is reported in Kézdi and Kónya (2011).

Figures 1-4 plot impulse response functions for selected shocks and variables, comparing the propagation of shocks between the two models. There are significant differences. The baseline model produces a much lower GDP response to a monetary policy shock, in line with Jakab, Vonnák and Várpalotai (2006) and Vonnák (2007). The response of employment to a technology shock is more muted in the SM model, and turns positive after two quarters; it is always negative in the EHL model. The UIP shock has a bigger impact on inflation, and a smaller one on GDP in the SM model than in the EHL model, in line with Vonnák (2010). The same finding emerges - even more dramatically - for the labor supply shock. Overall, we find that while the estimated parameters are quite close, the propagation of shocks in the SM model is more in line with VAR evidence for Hungary.

$<$ Figures 1-4 about here >

These results are particularly interesting because we allow for slow employment adjustment in the EHL model (see above). One important difference, however, remains: wages and employment are less connected in the SM model than in the EHL model. This is so because in a frictional labor market wages are more redistributive than allocative, due to the presence of a surplus in employment relationships. Therefore, we conjecture that the data rejects the tight relationship between (period) wages and (short-run) employment changes in favor of a more flexible approach used in the SM model.

For similar degrees of wage rigidity, the employment - and hence GDP - response is more sluggish in the SM model than in the EHL model. As Arsenau and Chugh (2012) explain, a very large degree of real wage rigidity is needed in the search-and-matching model to make employment volatility similar to that predicted by the EHL approach. Our estimation procedure, however, does not find that: neither the extrinsic wage rigidity parameters $\left(\gamma_{w}, \delta_{w}\right)$ nor the intrinsic wage rigidity parameters $(\eta$, $\left.z_{u}, \bar{\chi} / \bar{\lambda}\right)$ are particularly large. In Arsenau and Chugh (2012) the former are zero, while the latter follow the small surplus calibration of Hagedorn and Manovskii (2008), and hence deliver very rigid real wages. Our medium scale DSGE model is able to fit data moments with a combination of shocks instead, and does not require the same degree of wage rigidity (see also for Konya and Krause, 2009 for a similar result).

\subsection{The role of wage rigidity}

In this section we explore the role of wage rigidity for existing and new hires in shock propagation. This is a potentially important aspect of our model, and also connects to a large literature on the role of wage stickiness in models with labor market frictions (Shimer, 2005; Pissarides, 2009; Haefke, C., M. Sonntag, T. van Rens, 2013).

Figures 5 and 6 investigate the role of new hires wage rigidity ${ }^{11}$ in shock propagation. This aspect of the model is a novel feature of our analysis, hence we present two sets of IRFs to check whether

\footnotetext{
${ }^{10}$ This holds also for the other common parameters that we did not include in the table for brevity. The two parameters specific to the EHL mode, $\sigma_{w}$ and $\varphi$, are estimated, but the posteriors basically mimic the priors with means 6 and 1 , respectively.

${ }^{11}$ In the discussion that follows we sometimes use the abbreviation NHWR for brevity.
} 
distinguishing new hires wage rigidity is important. ${ }^{12}$ Given the very imprecise estimate of this parameter, we compare the baseline estimates to two alternative specifications: one where new hires wages are just as rigid as wages in existing jobs $\left(\delta_{w}=\gamma_{w}\right)$, and one where new hires' wages are fully flexible $\left(\delta_{w}=0\right)$. The former is the assumption in Gertler, Sala and Trigari (2008); while the latter is advocated in Pissarides (2009). We thus contribute to the growing literature on the importance of new hires' wage stickiness, by looking at its role in a fully fledged DSGE model.

$<$ Figures 5-6 about here >

As the figures show, the importance of $\delta_{w}$ is very much shock and variable dependent. ${ }^{13}$ In response to a monetary policy shock, the path of employment, and to a lesser extent GDP, is dependent on NHWR. Inflation and the real wage, on the other hand, are unaffected. Since the estimated $\delta_{w}$ is much closer to $\gamma_{w}$ than to 0 , the baseline and high rigidity impulse responses are close to each other. Nevertheless, in case of employment, even a small increase in the flexibility of new hires' wages have non-negligible effects.

For the labor supply shock, inflation, employment and GDP all respond differently as $\delta_{w}$ varies. In particular, flexible new hires wages lead to more amplification of this shock for all three variables. Even moderate flexibility leads to noticeable changes, but the case of $\delta_{w}=0$ clearly stands out in magnitude.

Overall, we conclude that at least for some shocks the flexibility of wages in new jobs is an important determinant of shock propagation. While our mean estimated value of $\delta_{w}$ is not very far from $\gamma_{w}$, the parameter is not identified very well in the data to leave enough ambiguity behind. New hires wage rigidity has potentially significant quantitative implications in a medium scale DSGE model, and hence it is an issue that needs to be investigated further.

\subsection{Theoretical and historical shock decompositions}

In this section we explore the relative role of different shocks to explain movements in key model variables. We do this by presenting theoretical and historical shock decompositions for a selected set of variables.

$<$ Table 4 about here $>$

Table 4 presents the theoretical variance decomposition of a selected set of key variables in the model, using the posterior means for the parameter values and shock innovation sizes. GDP is mostly explained by technology shocks $\left(v_{a}, v_{i}\right)$, and to a lesser extent open economy shocks $\left(v_{x}, v_{p}^{m}\right)$, and the separation shock $\left(v_{\rho}\right)$. Domestic demand and nominal shocks play essentially no role for GDP.

Monetary policy shocks matter moderately for inflation, whose fluctuations are explained mostly by the cost push shock $(\mu)$, the investment specific shock, the UIP shock and a combination of other shocks. The domestic interest rate shock is important for consumption, and plays a significant role for exports and imports. Investment is basically explained by its own shock, which may indicate that the model's internal propagation for investment is weak.

Labor market shocks are the most important for labor market variables (employment and the real

\footnotetext{
${ }^{12}$ In response to a technology shock the differences are very small (not reported). The UIP shock IRFs are very similar to monetary policy shocks, i.e. NHWR is important for employment only (not reported).

${ }^{13}$ Note that the real wage IRFs are very similar throughout, which should not be a surprise. Job destruction and job creation are low in Hungary, so average wage inflation is mostly determined by the evolution and rigidity of wages in existing jobs.
} 
wage). This is especially true for employment, where separation shocks account for $2 / 3$ of the variation. This contrasts with Shimer (2005), who argue that in the US, job creation is the main cyclical driver of (un)employment. Elsby, Hobijn and Sahin (2013) show, however, that in continental European economies job separation is equally important. Our result is thus closer to them than to Shimer (2005). ${ }^{14}$

Perhaps surprisingly for a highly open economy, open economy shocks play a modest role, with the exception of imports. The UIP shock, in particular, is significant only for inflation and exports. This may be an artifact of our sample period: the external financing premium was low and stable in most of this period, and became very important in the crisis years. For reasons we detailed above, however, we do not feel confident that our detrended and linearized model can adequately capture the crisis experience of Hungary. For a more tailored approach, see Benczúr and Kónya (2012).

Figures 7-9 show the estimated historical shock decompositions of GDP, inflation and employment. Given the large number of shocks, we grouped them into six categories: monetary, foreign (export demand, import price and UIP), cost-push (domestic and export markup), labor (labor supply and separation), supply (technology and investment), and demand (domestic interest rate and government spending). ${ }^{15}$

$<$ Figures 7-9 about here >

GDP in the sample period is primarily explained by supply shocks (changes in production efficiency), and in the latter part of the sample by foreign and demand shocks. The role of labor shocks was mostly small. In contrast, all shocks contributed to inflation variation. Cost-push shocks may be partly explained by the several changes in value-added taxes and regulated prices in Hungary during the period. Foreign shocks are important as well: note the large negatives in the first half of the sample (the "Chindia" effect).

Recall that in the theoretical variance decomposition, employment was mostly explained by labor shocks. This is not the case for the historical exercise, where foreign and demand shocks are also important. In particular, the estimation seems to capture the impact of fiscal stimulus in 2002-2004, and fiscal austerity in 2006-2008. Both the inflation and employment charts support the view, on the other hand, that monetary policy was lax in the second period. It is an interesting feature of the Hungarian economy that this mostly showed up in inflation and employment, but not in GDP (Jakab, Vonnák and Várpalotai, 2006; Vonnák, 2007).

\section{Conclusions}

This paper presented an estimated DSGE model of the Hungarian economy with search-and-matching frictions. Our results show that the structure of the labor market has a significant impact on monetary transmission. Shocks originating from the labor market, however, were not particularly important determinants of variables outside the labor market in our estimation period. This does not mean that labor market disturbances are irrelevant, but their effect may operate on a longer horizon than what

\footnotetext{
${ }^{14}$ Another difference is that we focus on employment instead of unemployment. If labor force participation (not in our model) affects these differently, the measured role of inflows and outflows in the two-state model might also be different. See Elsby, Hobijn and Sahin (2013b) for some new evidence on the participation margin, and Campolmi and Gnocchi (2011) for putting participation into a DSGE model.

${ }^{15} \mathrm{We}$ omit the role of initial conditions on the figure, it can be computed by subtracting the sum of the shock contributions from the total.
} 
our model captures. Difficulties in jointly modeling search frictions and sticky prices may also contribute to this finding.

Wage rigidity in existing jobs is fairly high, and it is an empirically important feature of the model. We also find that the extent of the flexibility of new hires wages is quantitatively important for shock propagation. This finding is, to the best of our knowledge, novel in the literature on search frictions in medium scale DSGE models.

Foreign shocks, especially to export demand and to the exchange rate, play a moderate role in the Hungarian economy. This, however, could be due to the selection of the sample period. Including the crisis years after 2008 would likely change this conclusion, but our modeling framework is not equipped to handle large shocks. This is an important avenue for future investigation.

Finally, comparing our estimates to an alternative DSGE model reveals that our structurally more rigid labor market leads to a more realistic picture of the Hungarian economy. In particular, we find a better overall fit, and smaller output responses to various shocks, which is more in line with VAR evidence for Hungary.

\section{References}

Adolfson, M., S. Laséen, J. Lindé and M. Villani (2007). "Bayesian estimation of an open economy DSGE model with incomplete pass-through." Journal of International Economics, 72(2), p.481-511.

Albertini, J., G. Kamber and M. Kirker (2011): "An estimated small open economy model with frictional unemployment.” Reserve Bank of New Zealand, Discussion Paper Series DP 2011/04.

Andolfatto, D. (1996). "Business Cycles and Labor-Market Search." American Economic Review, 86(1), p.112-132.

Arseneau, D. and S. Chugh (2012). “Tax Smoothing in Frictional Labor Markets.” Journal of Political Economy, 120(5), p.926-985.

Benczúr, P. and I. Kónya (2012). "Interest Premium, Sudden Stop, and Adjustment in a Small Open Economy." Mimeo.

Benczúr, P. and A. Rátfai (2014). "Business Cycles Around the Globe: Some Key Facts.” Emerging Markets Finance and Trade, 50(2), p.102-109.

Berument, M. H., N. Dogan and A. Tansel (2009). "Macroeconomic Policy and Unemployment by Economic Activity: Evidence from Turkey.” Emerging Markets Finance and Trade, 45(3), p.21-34.

Bewley, T. (1999). Why Wages Don't Fall During a Recession. Cambridge, MA: Harvard University Press.

Blanchard, O. and J. Gali (2007). "Real Wage Rigidities and the New Keynesian Model.” Journal of Money, Credit and Banking, 39(s1), p.35-65.

Bodart, V. and O. Pierrard and H. Sneessens (2006). "Calvo Wages in a Search Unemployment Model." IZA Discussion Papers 2521, Institute for the Study of Labor (IZA). 
Campolmi, A. and S. Gnocchi (2011). "Labor Market Participation, Unemployment and Monetary Policy.” MNB Working Paper 2011/4, Magyar Nemzeti Bank.

Christoffel, K., K. Kuester and T. Linzert (2006). "Identifying the Role of Labor Markets for Monetary Policy in an Estimated DSGE Model.” Working Paper Series 635, European Central Bank.

Elsby M, B. Hobijn and A. Sahin (2013a). "Unemployment Dynamics in the OECD.” The Review of Economics and Statistics, 95(2), p.530-548.

Elsby M., B. Hobijn and A. Sahin (2013b). "On the importance of the participation margin for market fluctuations.” Working Paper Series 2013-05, Federal Reserve Bank of San Francisco.

Erceg, C., D. Henderson and A. Levin (2000). "Optimal Monetary Policy with Staggered Wage and Price Contracts." Journal of Monetary Economics, 46(2), p.281-313.

Faia, E. (2008). "Optimal monetary policy rules with labor market frictions." Journal of Economic Dynamics and Control, 32(5), p.1600-1621.

Fujita, S. and G. Ramey (2007). "Job matching and propagation." Journal of Economic Dynamics and Control, 31(11), p.3671-3698.

Galuscak, K., M. Keeney, D. Nicolitsas, F. Smets, P. Strzelecki, M. Vodopivec (2012). “The determination of wages of newly hired employees: Survey evidence on internal versus external factors." Labour Economics, 19(5), p.802-812.

García-Cicco, J., R. Pancrazi, and M.Uribe (2010). “Real Business Cycles in Emerging Countries?” American Economic Review, 100(5), p.2510-2531.

Gertler, M., L. Sala and A. Trigari (2008). "An Estimated Monetary DSGE Model with Unemployment and Staggered Nominal Wage Bargaining." Journal of Money, Credit and Banking 40(8), p.1713-1764.

Haefke, C., M. Sonntag, T. van Rens (2013). “Wage rigidity and job creation.” Journal of Monetary Economics, 60(8), p.887-899.

Hagedorn, M. and I. Manovskii (2008). "The Cyclical Behavior of Equilibrium Unemployment and Vacancies Revisited.” American Economic Review, 98(4), p.1692-1706.

Hobijn, B. and A. Sahin (2009). "Job-finding and separation rates in the OECD.” Economics Letters, 104(3), p.107-111.

Jakab, Z., V. Várpalotai and B. Vonnák (2006): "How does monetary policy affect aggregate demand? A multimodel approach for Hungary”, MNB Working Paper 2006/4, Magyar Nemzeti Bank.

Jakab, M. Z. and B. Világi (2008). "An Estimated DSGE Model of the Hungarian Economy." MNB Working Paper 2008/9, Magyar Nemzeti Bank.

Kézdi, G. and I. Kónya (2011). "Wage setting in Hungary: evidence from a firm survey." Working Paper Series 1378, European Central Bank.

Kónya, I. and M. Krause (2009). "Wage and Labor Market Dynamics in Europe and the United States.” Mimeo. 
Magyari, I. (2010). "Disentangling the Impact of Eurozone Interest Rate Movements on CEECs' Business Cycle Fluctuations: The Role of Country Spread.” Master Thesis, Central European University.

Merz, M. (1995). "Search in the Labor Market and the Real Business Cycle.” Journal of Monetary Economics, 36(2), p.269-300.

Mortensen, D. and C. Pissarides (1994). "Job Creation and Job Destruction in the Theory of Unemployment.” Review of Economic Studies, 61(3), p.397-415.

Petrongolo, B. and Pissarides, C. (2001). "Looking into the black box: A survey of the matching function.” Journal of Economic Literature, 39(2), p.390-431.

Pissarides, C. (2009). “The Unemployment Volatility Puzzle: Is Wage Stickiness the Answer?” Econometrica, 77(5), p.1339-1369.

Schmitt-Grohe, S. and M. Uribe (2003). "Closing Small Open Economy Models." Journal of International Economics, 61(1), p.163-85.

Shimer R. (2005). “The Cyclical Behavior of Equilibrium Unemployment and Vacancies.” American Economic Review, 95(1), p.25-49.

Smets, F. and R. Wouters (2003). "An Estimated Stochastic Dynamic General Equilibrium Model of the Euro Area." Journal of the European Economic Association, 1(5), p.1123-1175.

Stahler, N. and C. Thomas (2012). "FiMod - A DSGE model for fiscal policy simulations." Economic Modelling, 29(2), p.239-261.

Trigari, A. (2006). “The Role of Search Frictions and Bargaining for Inflation Dynamics.” IGIER Working Paper No. 304, Bocconi University.

Vonnák, B. (2007). “The Hungarian Monetary Transmission Mechanism: an Assessment.” MNB Working Paper 2007/3, Magyar Nemzeti Bank.

Vonnák, B. (2010). "Risk premium shocks, monetary policy and exchange rate pass-through in the Czech Republic, Hungary and Poland.” MNB Working Paper 2010/1, Magyar Nemzeti Bank.

Yashiv, E. (2006). "Evaluating the performance of the search and matching model." European Economic Review, 50(4), p.909-936.

Yilmazkuday, H. (2008). "Structural Breaks in Monetary Policy Rules: Evidence from Transition Countries.” Emerging Markets Finance and Trade, 44(6), p.87-97. 


\section{Tables}

Table 1: Calibrated parameters

\begin{tabular}{lcc}
\hline Parameters & Notation & Values \\
\hline Discount factor & $\beta$ & 0.99 \\
Depreciation rate & $\delta$ & 0.027 \\
Capital share in GDP & $\alpha$ & 0.34 \\
Import share in gross output & $\alpha_{d}$ & 0.588 \\
Import/domestic elast. & $\xi$ & 0.8 \\
Debt elast. of int. rate & $\psi$ & 0.01 \\
Capacity util. elast. & $v$ & 5 \\
Elast. of intertemp. subst. & $\vartheta$ & 2 \\
Domestic markup & $\bar{\mu}$ & 0.1 \\
Export markup & $\bar{\mu}_{x}$ & 0.1 \\
Gov. cons. share in GDP & $\bar{g}_{y}$ & 0.1035 \\
Steady state NFA per GDP & $\bar{b}_{y}$ & -2.4 \\
Investment share in GDP & $\bar{i}_{y}$ & 0.24 \\
Unemp. replacement rate & $z_{u} / \bar{w}$ & 0.62 \\
Job finding rate & $\bar{s}$ & 0.19 \\
Unemployment rate & $\bar{u}$ & 0.08 \\
Separation rate & $\bar{\rho}$ & 0.0165 \\
Matching function elast. & $\sigma$ & 0.5 \\
Workers' bargaining power & $\eta$ & 0.5 \\
\hline
\end{tabular}


Table 2: Estimated parameters

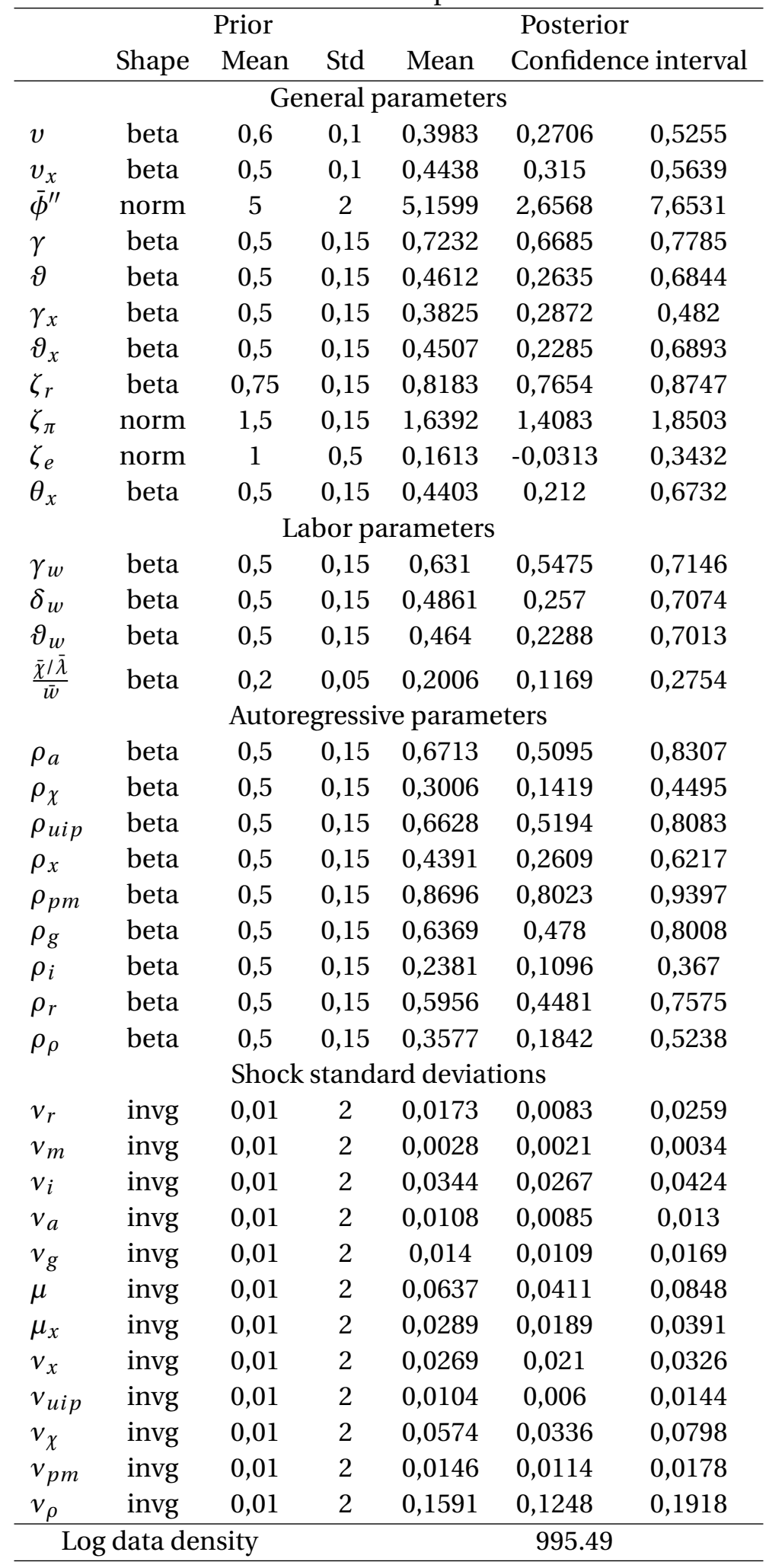


Table 3: Model comparison

\begin{tabular}{ccccccc}
\hline & Mean & \multicolumn{2}{c}{ Conf. int. } & Mean & \multicolumn{2}{c}{ Conf. int. } \\
& \multicolumn{3}{c}{ SM model } & \multicolumn{3}{c}{ EHL model } \\
\hline$\gamma$ & 0,7232 & 0,6685 & 0,7785 & 0,7553 & 0,7033 & 0,8061 \\
$\vartheta_{p}$ & 0,4612 & 0,2635 & 0,6844 & 0,5026 & 0,3464 & 0,6508 \\
$\gamma_{x}$ & 0,3825 & 0,2872 & 0,482 & 0,4082 & 0,3167 & 0,4986 \\
$h$ & 0,3983 & 0,2706 & 0,5255 & 0,4853 & 0,3433 & 0,6269 \\
$\gamma_{w}$ & 0,631 & 0,5475 & 0,7146 & 0,4824 & 0,3578 & 0,6057 \\
$\delta_{w}$ & 0,4861 & 0,257 & 0,7074 & - & - & - \\
$\vartheta_{w}$ & 0,464 & 0,2288 & 0,7013 & 0,3819 & 0,1787 & 0,5647 \\
\hline Log data density & & 995.49 & & & 981.77 & \\
\hline
\end{tabular}

Table 4: Variance decomposition for selected variables

\begin{tabular}{cccccccccc}
\hline & & $g d p$ & $c$ & $i$ & $n$ & $\pi$ & $w$ & $y_{x}$ & $y_{m}$ \\
\hline Int. premium & $v_{r}$ & 3,74 & 36,36 & 4,38 & 8,46 & 10,3 & 7,49 & 11,68 & 11,48 \\
Investment & $v_{i}$ & 16,55 & 27,35 & 82,23 & 6,83 & 26,97 & 5,79 & 38,05 & 25,41 \\
Technology & $v_{a}$ & 55,31 & 2,79 & 1,01 & 0,47 & 4,72 & 2,24 & 5,32 & 4,4 \\
Separation & $v_{\rho}$ & 4,27 & 0,38 & 0,17 & 59,64 & 0,28 & 0,54 & 0,17 & 0,14 \\
Labor supply & $v_{\chi}$ & 0,92 & 0,02 & 0,01 & 12,72 & 0,01 & 44,89 & 0,03 & 0,01 \\
Gov. spending & $v_{g}$ & 0,05 & 0,1 & 0,03 & 0,01 & 0,05 & 0,03 & 0,13 & 0,11 \\
Export demand & $v_{x}$ & 6,68 & 10,07 & 3,55 & 2,98 & 2,99 & 10,41 & 18,35 & 34,79 \\
Import price & $v_{p^{m}}$ & 9,56 & 14,94 & 6,44 & 4,36 & 3,88 & 18,98 & 5,93 & 20,21 \\
UIP & $v_{u i p}$ & 0,89 & 3,16 & 1,28 & 0,55 & 15,5 & 1,3 & 9,7 & 1,59 \\
Dom. markup & $\mu$ & 0,64 & 1,38 & 0,23 & 1,6 & 23,35 & 6,9 & 4,97 & 0,51 \\
Export markup & $\mu_{x}$ & 0,58 & 1,25 & 0,4 & 0,09 & 0,51 & 0,48 & 0,95 & 0,68 \\
Mon. policy & $v_{m}$ & 0,82 & 2,2 & 0,26 & 2,29 & 11,44 & 0,95 & 4,72 & 0,66 \\
\hline
\end{tabular}




\section{Figures}

Figure 1: Shock responses in the SM and EHL models: monetary policy shock
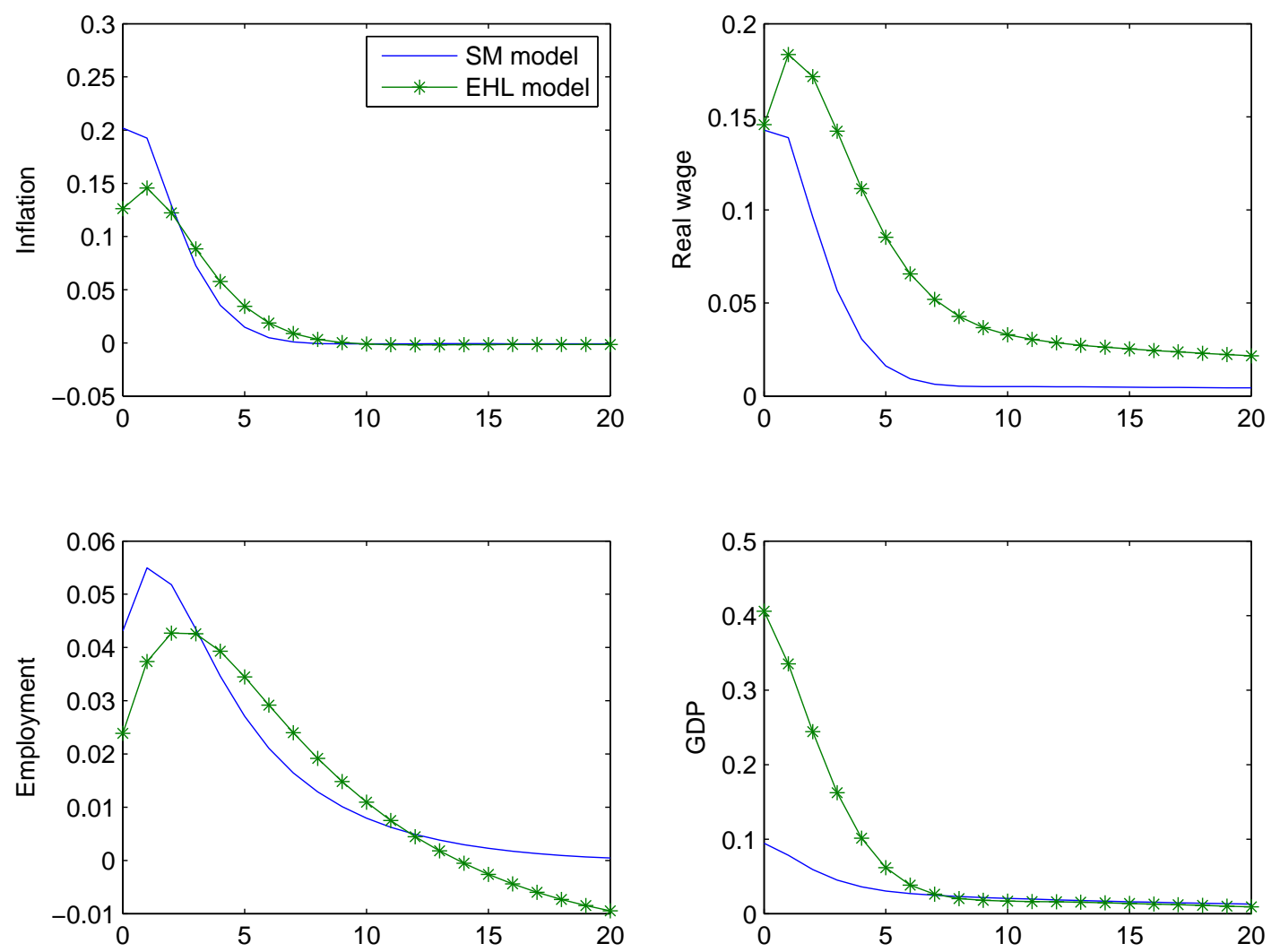
Figure 2: Shock responses in the SM and EHL models: technology shock
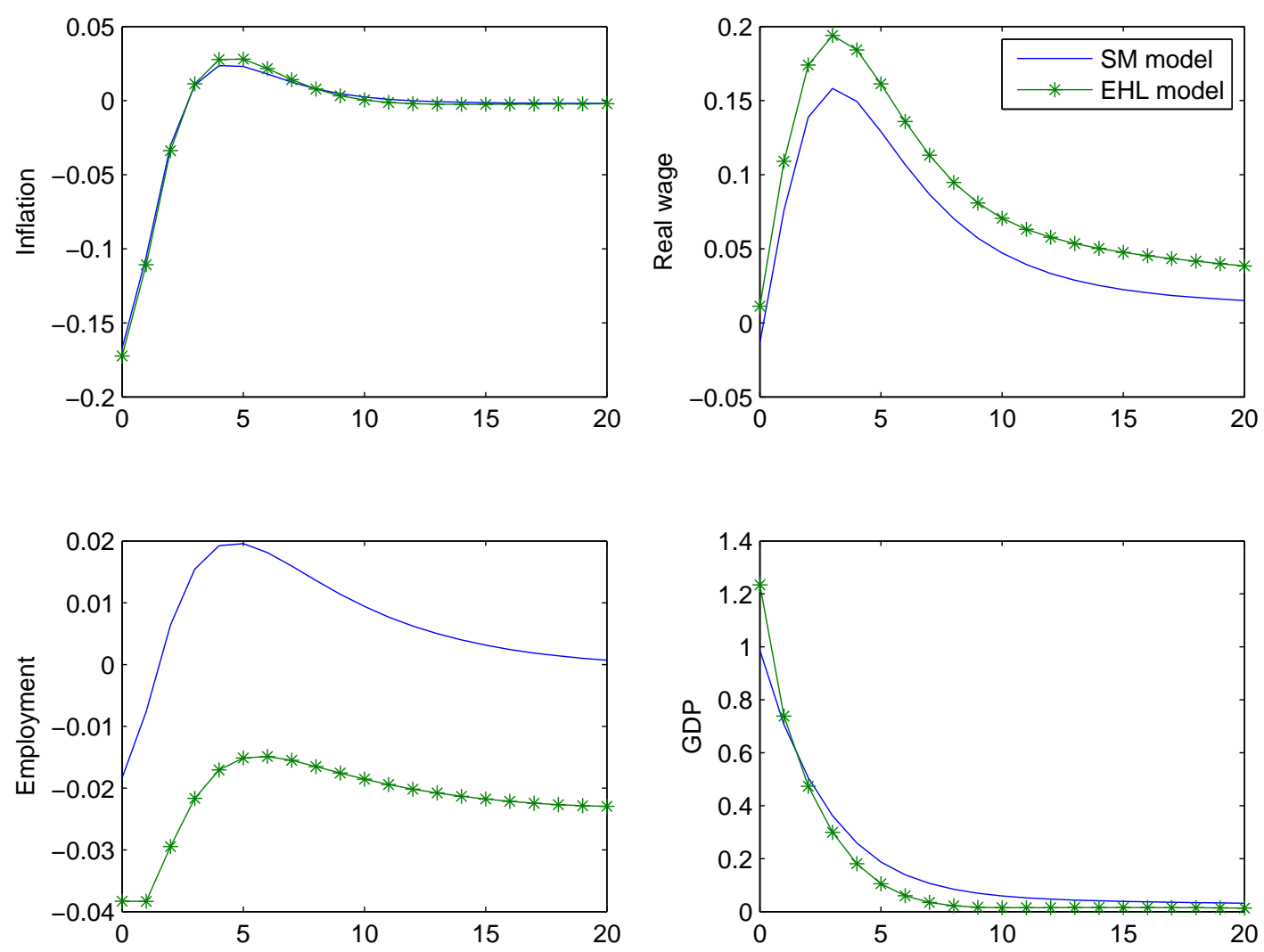

Figure 3: Shock responses in the SM and EHL models: UIP shock
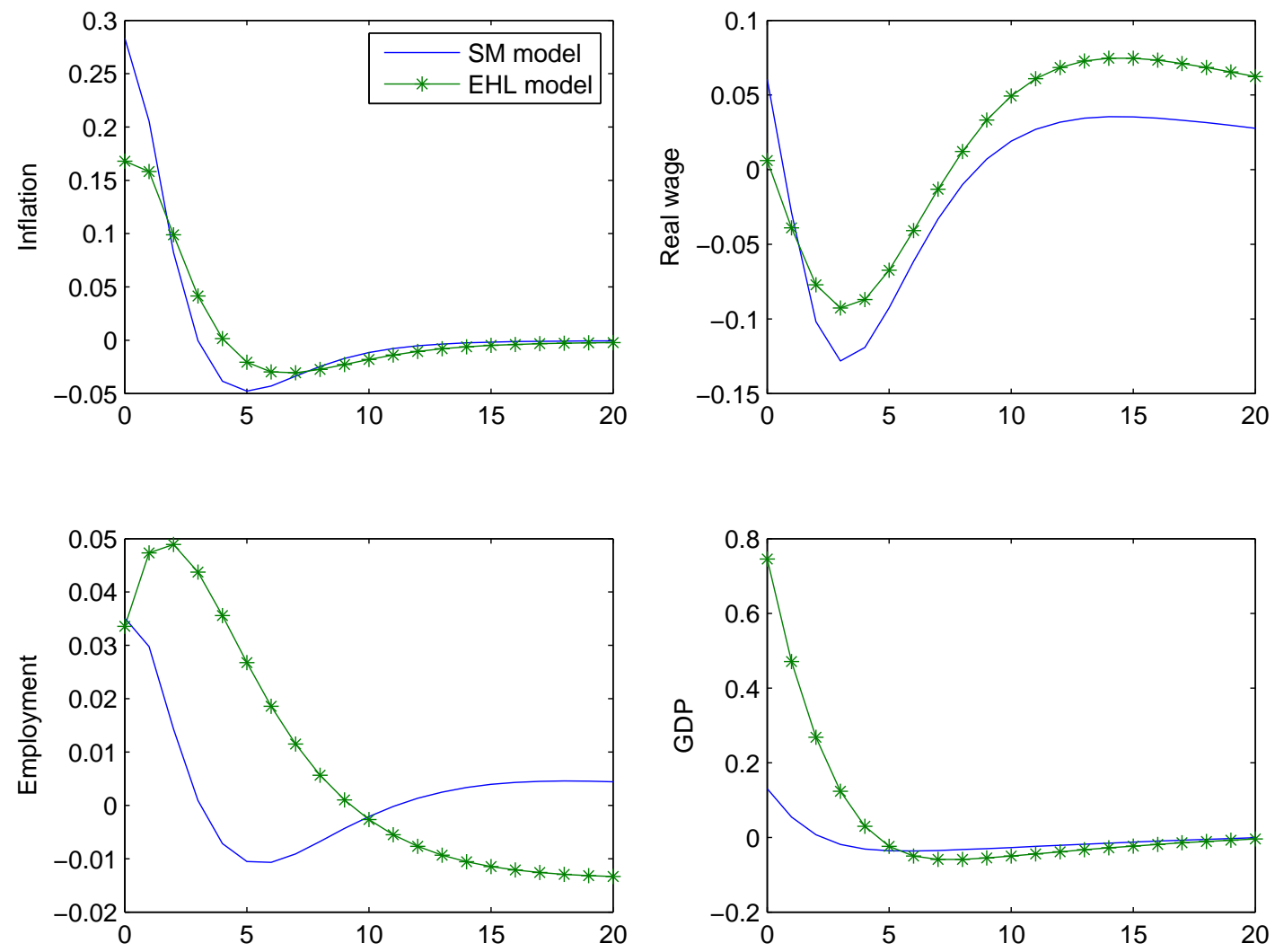
Figure 4: Shock responses in the SM and EHL models: labor supply shock
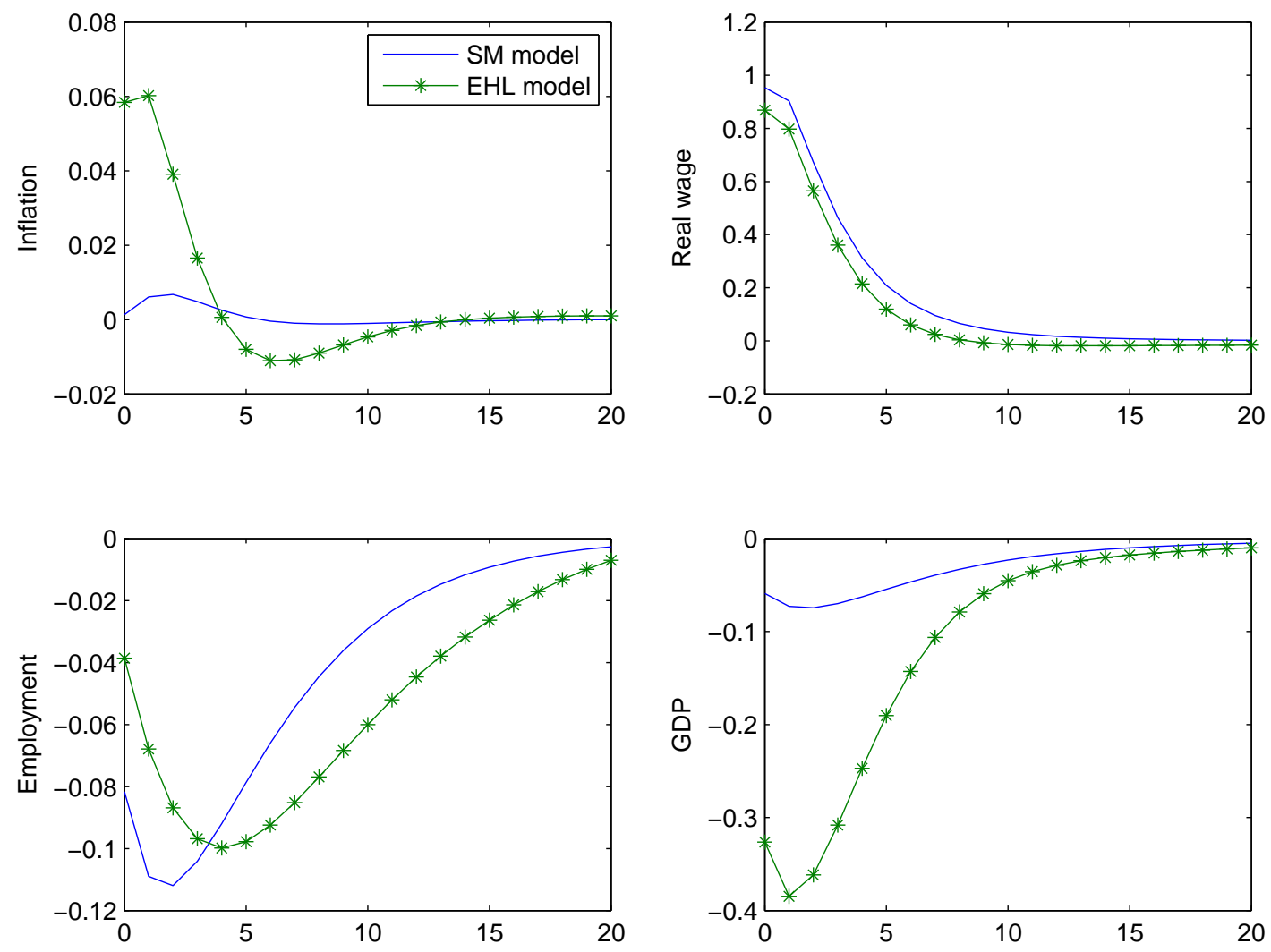

Figure 5: New hires' wage rigidity - monetary policy shock
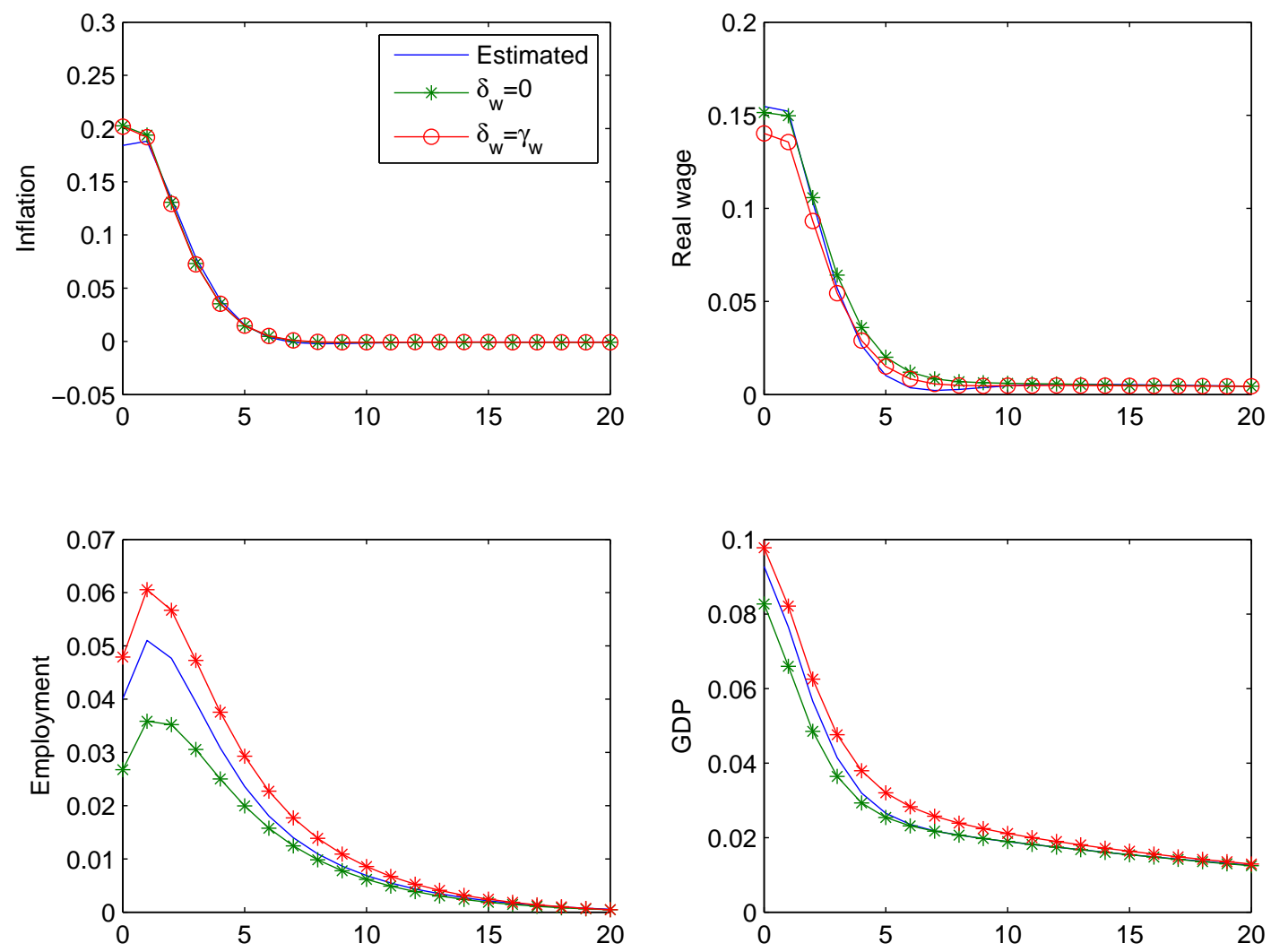
Figure 6: New hires' wage rigidity - labor supply shock
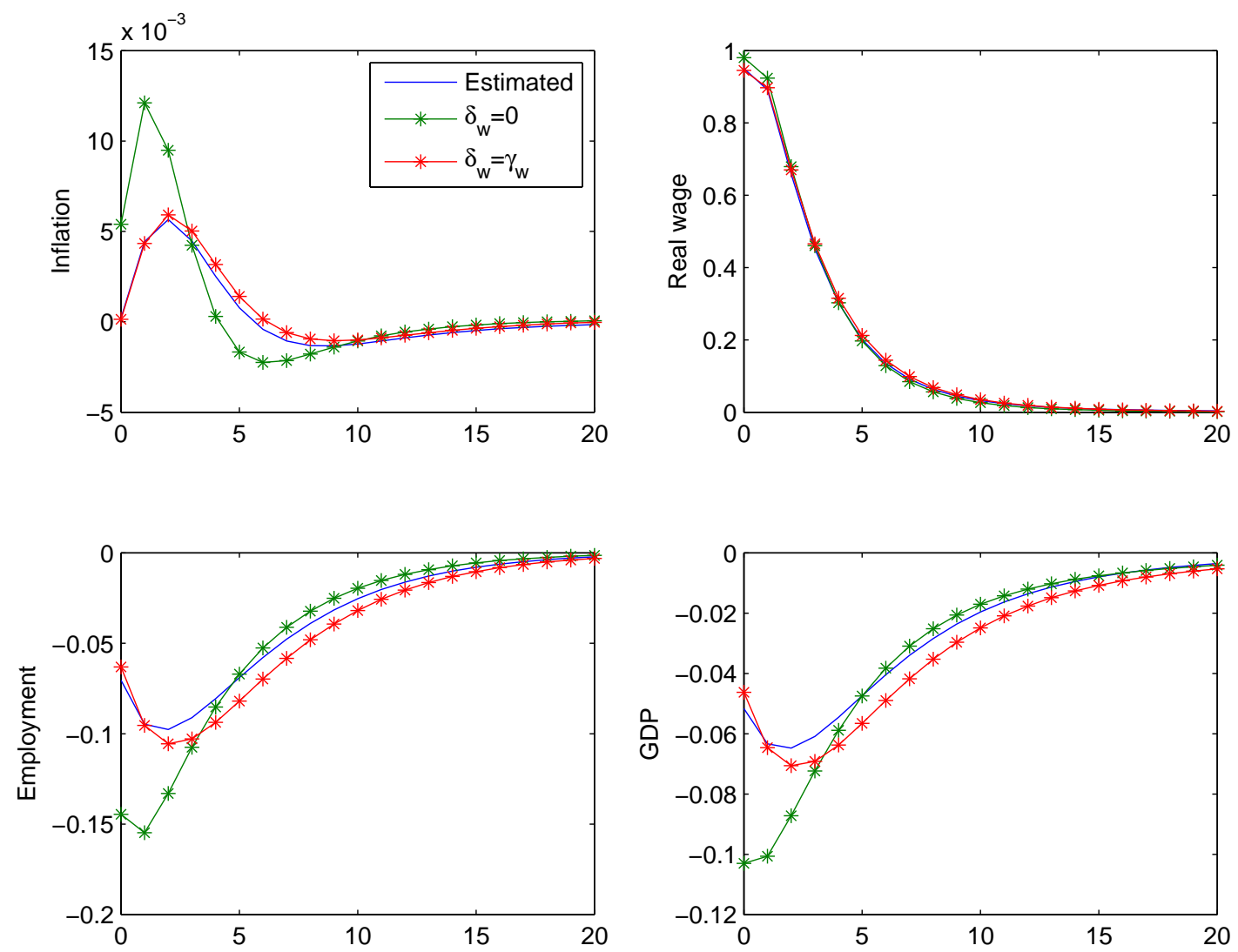

Figure 7: Historical shock decomposition: GDP

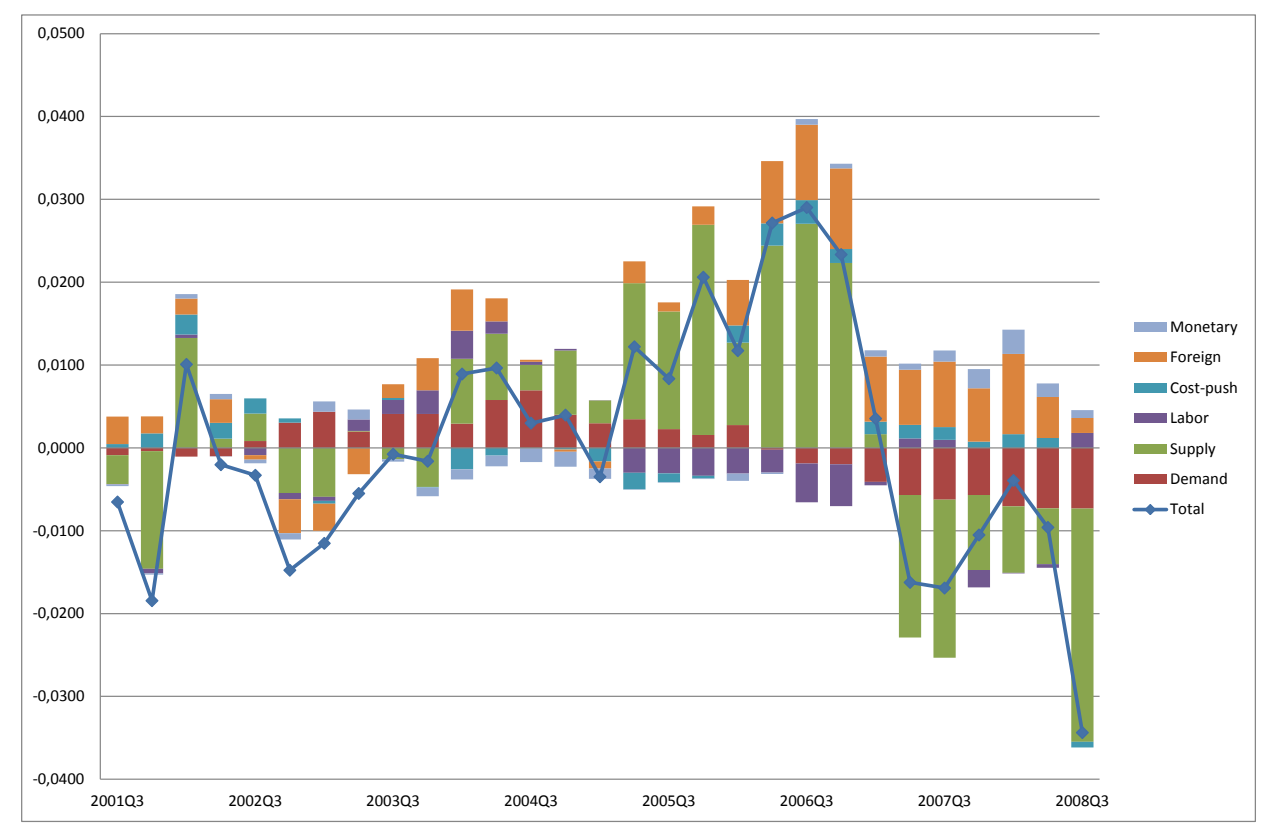


Figure 8: Historical shock decomposition: inflation

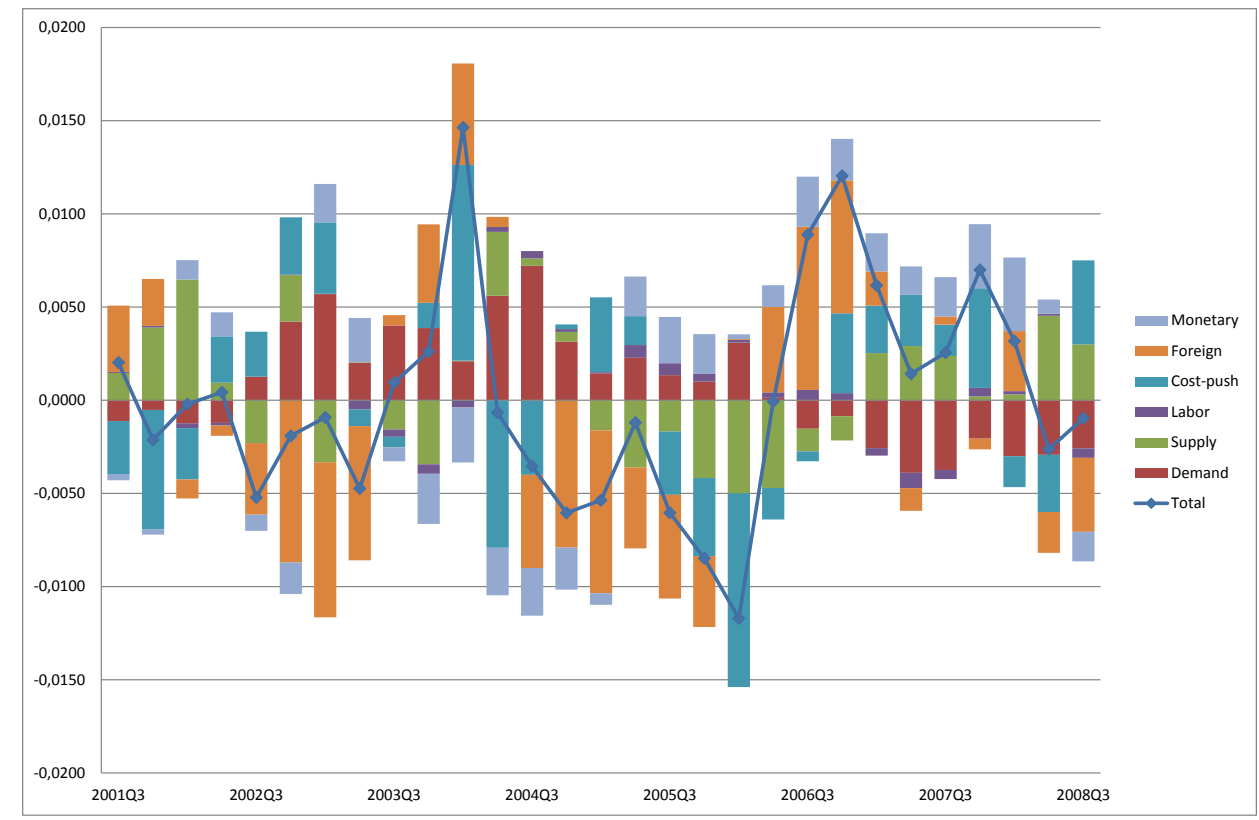

Figure 9: Historical shock decomposition: employment

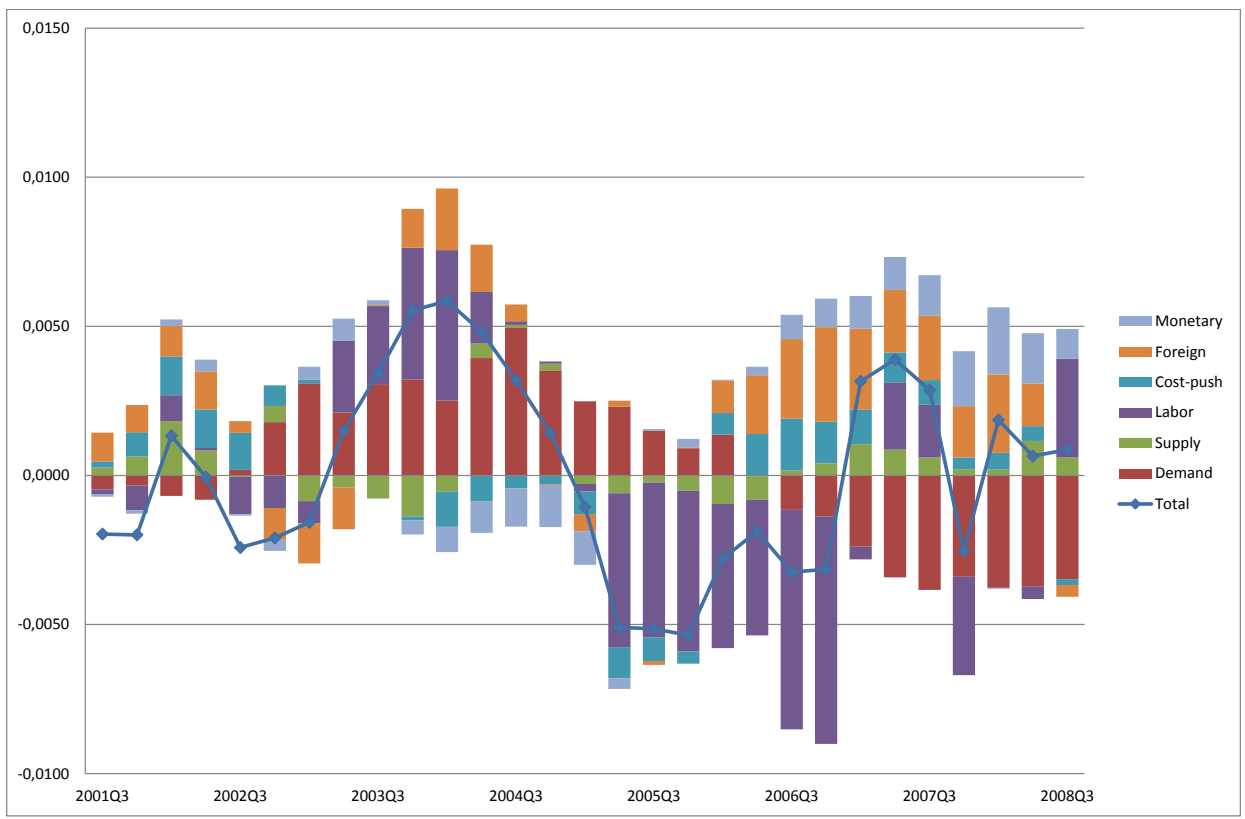

